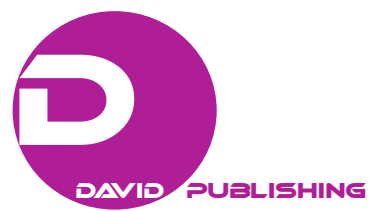

\title{
The Tamale Local Boy Scouts Association in the Northern Territories Protectorate in the 1920s
}

\author{
Doris S. Essah \\ University of Ghana, Legon, Ghana
}

\begin{abstract}
In 1907, military leader Robert Baden-Powell started the Boy Scouts Association in England as the British colonial government officers instituted Tamale village as the administrative centre of the Northern Territories Protectorate. Sam Yarney worked with Frank Collyer the European bank cashier and scoutmaster who started the Boy Scouts in the Gold Coast Colony in 1914, the year the First World War started. In 1922, Governor Gordon Guggisberg, who was brigadier general during the war was the chief scout. He reorganized the Local Boy Scouts Association in the Tamale Government School that received select boys from various schools in the Northern Territories Protectorate. The schoolboys excelled in the Standard VII and Civil Service Examinations to work with the government institutions and train as teachers and telegraphists. Arthur James Philbrick the chief scout commissioner of the Northern Territories employed Yarney as the assistant scout commissioner in the Southern Province to take on the staff of the reorganized Tamale Local Boy Scouts Association and register the 1st Tamale Troop. The scout officers subscribed to a Scout Fund to buy kit, for the schoolboys who passed the Tenderfoot Tests to buy uniforms and perform at events.
\end{abstract}

Keywords: Local Boy Scouts Association, 1920s, uniforms, Tamale Government School, Northern Territories Protectorate, Gold Coast Colony

\section{Introduction}

In 1907, the British colonial government officers instituted Tamale village as the administrative centre of the Northern Territories Protectorate (MacGaffey, 2006; 2009), as Robert Baden-Powell started the Boy Scouts Association in England (Johnston, 2014; 2015; Block \& Proctor, 2009; Pryke, 1998). The emphasis of the Boy Scouts was imperial nationalism and how to educate the youth to fit into the middle-class (Pryke, 1998). In 1914, when the Boy Scouts Association had the largest sphere of influence among the youth in the British Empire and the world (Pryke, 1998), Frank Collyer, a European bank cashier and scoutmaster, started the Boy Scouts Association in the Gold Coast Colony (ADM 56/1/317) ${ }^{1}$. The Boy Scouts Associations that registered in the Southern Province of the Northern Territories Protectorate were among the Gonja and Dagomba tribes, who lived in either villages, or towns with a number of square miles of farms (ADM 56/1/146 ${ }^{2}$; ADM 56/1/338 ${ }^{3}$;

\footnotetext{
Doris S. Essah, Doctoral Degree in History, Lecturer, Legon History Department, University of Ghana.

${ }^{1}$ Public Records and Archives Administration Department, Accra, ADM 56/1/317 Boy Scouts Local Association-NT.

2 Public Records and Archives Administration Department, Accra, ADM 56/1/146 Northern Territories.

3 Public Records and Archives Administration Department, Accra, ADM 56/1/338 Boy Scouts Local Association Tamale N.T. 9/3/22-4/9/24.
} 
ADM 56/1/67 ${ }^{4}$; ADM 56/1/129 ${ }^{5}$ ). Among the Gonja, the Boy Scouts were at Salaga, where Duncan-Johnstone, the European district commissioner and scout commissioner, was nominated secretary of the Northern Territories Scout Council. The Salaga Local Boys Scouts Association collapsed when he had to relocate to the Ashanti Colony. Among the Dagomba, the Boy Scouts were at the rural capital Yendi (the Junior Trade School) and Tamale. Since the Education Department, not the Supreme Council of the Boy Scouts Association, registered and fashioned Junior Trade Schools, the schoolboys behaved as Boy Scouts but the Yendi Trade School did not have a Local Boy Scouts Association (ADM 56/1/338). This paper uses archival documents to research the Tamale Local Boy Scouts Association that the Gold Coast colonial government officers who were scout officers aimed to smarten during the 1920s. The question asked is: How did the scoutmasters have kit including scout uniforms and educate the Boy Scouts in the Tamale Government School?

In April 1921, Education Department officer Robertson corresponded with the Boy Scouts officers that the Boy Scouts (and Troop) at Tamale Government School organize per the rules of the Local Boy Scouts Association (ADM 56/1/338). Tamale Government School selected boys from various schools in the Northern Territories to excel in the Standard VII and the Civil Service Examinations and have training for a profession. Graduates worked in government institutions such as Agriculture, Education and Veterinary and Cadbury and trained as teachers and telegraphists (ADM 56/1/323 $)$. The Tamale Troop was not controlled by a church or school but was organized by Philbrick, the chief scout commissioner of the Northern Territories (ADM 56/1/338). Although the lot of schoolboys desired to become Boy Scouts, the scout officers estimated a cast of thirty schoolboys and kit for the Tamale Local Boy Scouts Association.

Sam Yarney worked as a registered assistant scoutmaster at the Winnebah Area Local Association, where the Boy Scouts started in the Gold Coast. In February 1922, he requested that since the Local Boy Scouts Association was registering at Tamale, the chief commissioner of the Northern Territories employed him assistant scout commissioner with the contractual abilities of a scoutmaster. Yarney had worked in 1914 with District Commissioner Lamond during the riot that killed 38 people at Berracoe close to Winnebah, and was working with the Boy Scouts Association when the Gold Coast Police had to fight with the French against the Germans at Lome in Togo during the Great War. In January 1915, Yarney worked as a registered assistant scout commissioner then a drillmaster. Yarney regimented the Tamale Boy Scouts to become the Tamale Local Boy Scouts Association and Troop. The assistant secretary was Bowker, the district commissioner at Tamale (ADM 56/1/317).

\section{The Tamale Local Boy Scouts Association}

In May, the Tamale Local Boy Scouts Association had the first meeting at Bowker, the district commissioner's court. The aim was to take on staff, apply for warrants for the staff, request for a library, register the troop, and buy uniforms. Yarney, the assistant scout commissioner, talked about the Policy, and Organization of the Boy Scouts Movement. Philbrick, the chief scout commissioner, applied to the chief scout in Accra for warrants for all the staff and the Tamale Troop had to register and have a registration number from England. In July, Philbrick received the warrants for the scoutmasters and assistant scoutmasters of the Tamale

\footnotetext{
${ }^{4}$ Public Records and Archives Administration Department, Accra, ADM 56/1/67 Tamale Township 13/1/08-19/7/30.

${ }^{5}$ Public Records and Archives Administration Department, Accra, ADM 56/1/129 Tamale Town-Improvement of 5/5/11-28/3/30.

6 Public Records and Archives Administration Department, Accra, ADM 56/1/323 Gov't Sch-Education Correspondence 27/8/19-24/6/30.
} 
Local Boy Scouts Association and the 1st Tamale Troop. Each scout officer and Boy Scout had to have a membership and enrolment card (ADM 56/1/338; ADM 56/1/317).

The objective of the Tamale Local Boy Scouts Association was to have a school farm and the schoolboys have private work to benefit from the money and increase the Troop Fund. The schoolboys' wages were not paid to the Troop Fund (ADM 56/1/317).

\section{Scout Uniforms}

The decision made at the first meeting of the Supreme Council of the Boy Scouts Association in March 1922 was that boys had to wear Boy Scouts uniforms when they passed the Tenderfoot Tests within three months of joining the Tamale Local Boy Scouts Association (ADM 56/1/338; ADM 56/1/317; ADM $56 / 1 / 331^{7}$ ). At the first meeting of the Tamale Local Boy Scouts Association in May, 30 boys could pass the Tenderfoot Tests and the meeting resolved that the chief commissioner asked the "Government" for a grant for uniforms as sold at the Scottish Mission Book Depot at Accra. In June and July 1922, the Boy Scouts did not have uniforms for boys who passed the Tenderfoot Tests. Philbrick, the chief scout commissioner, wrote to the secretary at the Colonial Headquarters, "the provision of uniforms for the boys is a question of great difficulty". He then claimed that the Boy Scouts Troop which needed uniforms could not "be the subject of charity". The Boy Scouts Association could have a "central fund" to put $£ 30$ up for school uniforms. In November, the Boy Scouts Association requested European officers to pay ten shillings yearly as subscription to start a fund to buy kit to develop the Boy Scouts Association in the Northern Territories. Major Walker Leigh, the scout deputy camp chief and the chief commissioner, paid $£ 10$ each to the 1st Tamale Troop. The Boy Scouts Association paid for equipment but brainstormed against offering the Boy Scouts uniforms. The Boy Scouts yearned to retain their uniforms and paid in installments into the Scout Fund (ADM 56/1/317).

Scout officers obviated paying customs duty for uniforms. In December, the mailman inspected the pieces of imported uniforms Yarney had bought. Yarney wrote to Major Walker-Leigh, the deputy chief commissioner and deputy scout camp chief, for an endorsement to attach to the notice of the Order-in Council Number 24 of 1920 to avert paying customs duty for the uniforms imported for him and his Boy Scout Atta. His evidence that he should have a scout uniform was that Governor Guggisberg, the chief scout, had signed his warrant that made him the assistant scout commissioner of the Southern Province (ADM 56/1/338).

The rationale of the scout officers was that the 1st Tamale Troop had 32 boys who were obliged to have uniforms and reimburse the troop. In February 1923, Yarney wrote to Major Walker-Leigh, the deputy camp chief, that in two weeks, Boy Scout Williams and his caretaker Turkson the postmaster would settle in the Gold Coast. Since the scout officers would not send the uniform to him at the coast, Williams had asked for the 18 shillings that he deposited for a uniform (eight shillings in November and 10 shillings in December). The troop imported 32 uniforms and would keep the uniform not sent to him for his replacement.

Boy Scouts who graduated could register to stay with the school. In May, Nicholas Derimanu applied to the adjutant and the commandant of the Northern Territories Constabulary for printed permission for the chief scout commissioner to give him a Boy Scout uniform. Derimanu was a scout in school and had an enrolment card to remain a scout. European Captain Massie, the European government officer, conferred with African officer and parent S. L. Lomotey and the chief commissioner of the Northern Territories. Captain Massie wrote

\footnotetext{
${ }^{7}$ Public Records and Archives Administration Department, Accra, ADM 56/1/331 Boy Scouts 3/2/22-6/10/29.
} 
to Assistant Commissioner Yarney to give the uniform to Derimanu when he paid, since the government was trying Derimanu as a teacher.

On 14th October, 1923, the 1st Tamale Troop of Boy Scouts for the first time wore uniforms to their Sunday church parade and received 17 shillings from senior African officials at the church (ADM 56/1/317). The Boy Scouts received a shilling each from Johnson, Swatson, Etsuah, Allotey, and Blankson and four shillings from S. L. Lomotey and had a high opinion of S. L. Lomotey, Dsane, Sarpong, and J. B. Lomotey who had children who were Boy Scouts (ADM 56/1/338). Major Walker-Leigh, the deputy camp chief, then left for England with $£ 19$ of Scout Funds to buy paraphernalia for the Boy Scouts.

Yarney wrote to Major Walker-Leigh that Major Wallace was attracted to the Boy Scouts Association and "automatically becomes an ex-officio Commissioner" (ADM 56/1/317). On 27th October, Major Wallace wrote a circular: "Uniform for Scout Boys" about how Major Walker-Leigh, the scout deputy camp chief, was unsurpassed in rendering European subscribers. He and the chief commissioner had paid the largest money $£ 10$ each to import uniforms for the Boy Scouts. The boys were zealous but did not have the resources to buy the uniforms and depended on parents and guardians. Major Wallace held that parents and guardians had to pay for the Boy Scouts uniform as "requirements in two installments - commencing at the end of the month". Yarney told the scout commissioner, "without a word from the Scout Commnr nothing more would be steadily coming into the Scout Fund". Yarney anticipating that the next Monday was pay-day wrote a circular for the parents and guardians of a schoolboy in the 1st Tamale Troop to pay for his uniforms (ADM 56/1/338).

Six Boy Scouts paid for the uniforms. Four Boy Scouts deposited money for the uniforms (ADM 56/1/317). Ex.-Sgt. Alhandu Moshi deposited money for a uniform for his son Bukare. On 1st November, he paid 11 shillings and nine pence. When he paid the remaining 11 shillings, he would receive the Boy Scouts uniform. The value of the pieces of the Boy Scouts uniform was: a hat cost four shillings and three pence, a scarf or neckerchief 11 pence, a shirt six shillings and three pence, shorts five shillings and six pence, a belt two shillings and three pence, a shoulder knot two pence, a whistle eight pence, a troop name tab six pence, a stripe one pence, a knife one shilling six pence, Lanyard three pence, a Tenderfoot (cloth) badge two pence, and a 2nd Class Badge three pence. Ex-Sgt. Moshi did not pay the rest of the money for Bukare's uniform and did not get the uniform when they took off for Kratchi. Yarney had to return his money (ADM 56/1/338).

In February, the scout commissioner of the Southern Province wrote that the October circular had not made the parents and guardians of Boy Scouts procure the uniforms. The Boy Scouts Association:

[I]s supposed to be more or less self supporting, and good scouts, by the exercise of thrift and industry, are expected to buy their own uniforms, but conditions up here make it difficult for the boys to employ their spare time in money producing occupations. Hence quite generous subscriptions have been made in support of the movement in Tamale.

These have to be used to defray other expenses connected with the movement and the 1st Tamale Troop cannot continue to flourish unless parents and guardians come forward and do their bit by paying for the uniforms. The money is now badly needed. Major Walker-Leigh has kindly got a lot more equipment and this is now on the way out from England. We want money for the freight etc.

Major Wallace wrote that the 1st Tamale Troop financed other charges. Parents and guardians should pay for their children's uniforms to appreciate the children in uniform, for the children not to "feel ashamed that the uniform he is wearing is not paid for", and for the Local Boy Scouts Association to hit the target. The parents and guardians said they lacked money (ADM 56/1/317; ADM 56/1/338). 


\section{Boy Scouts Books, Instructing and Testing}

In January 1922, the Boy Scouts officers planned at Accra that the Local Boy Scouts Associations have a collection of books for a library. In May, at the meeting of the Tamale Local Boy Scouts Association, the chief commissioner of the Northern Territories applied to the Supreme Council at Accra for the books. In September, Yarney, the assistant scout commissioner in the Southern Province, wrote to the chairman that the troop officers did not have "a single book on hand". Yarney scripted that since the government could not stock books for the troop, the chairman should approve for the treasurer to buy the required books. The troop did not have books and the officers instructing did not have "previous scouting knowledge" but Yarney did not want the establishment of the Local Boy Scouts Association to become vain. In September he asked District Commissioner Bowker who was the chairman of the Local Boy Scouts Association at Tamale to approve that the treasurer wrote a cheque to the Bank of British West Africa Limited at Kumasi for the Boy Scouts kit.

Robert Baden-Powell had published Rovering to Success for the young men who learned technical and cadet training (Johnston, 2015). The Local Boy Scouts Association in the colonies and territories ordered books from Jack Sharp at Whitechapel, Liverpool. In November, Jack Sharp did not have the books Tracking and Pathfinding and Cyclists Scout's Training and suggested for the schoolboys Rovering to Success for two shillings and six pence, "selling very well" in Liverpool. The Local Boy Scouts Association ordered Scouting Games and Scouting for Boys for two shillings and six pence each, How to Run a Troop and Camping Book one shilling and six pence each, Boy Scout Tests and How to Pass Them four shillings, Signalling: By Many Methods one shilling, Book on Bugle Calls and Book on Compass one pence each and Book on Ambulance four pence.

In February, 10 boys passed the Tenderfoot Test and had Boy Scouts uniforms. They learned for the Second Class Tests, as new schoolboys learned for the Tenderfoot Tests. The patrols were required to learn: survey, maps, roads, and about the district; and carpentry and masonry. Medical officers would train the Boy Scouts about sanitation and First Aid. Lieutenant Colonel Whittall aimed that new boys would enroll as Cub Scouts that is schoolboys 8-12 years old. In April 1923, Major Walker-Leigh, the deputy camp chief, made the Boy Scouts Association at the Imperial Headquarters order books for the Cub Scouts and Boy Scouts. The Wolf Cub's First Book cost three pence, The Cub Book of Test four pence, The Wolf Cub's Handbook and The Patrol System two shillings six pence each, The Boy Scout (Music for Scouts), Yarns for Boy Scouts, and Things All Scouts Should Know two shillings each, Plays for Scout Entertainments nine pence, and The Ginger Beer Party and Crossing the Rubicon one shilling and six pence each.

As the Local Boy Scouts were international, the scout officers in England had to deal with their stance on "white supremacy" based on race, nationality, and class. The scout officers in England had to reconcile imperialism and internationalism, that internationalism was the ultimate of an imperialism that involved the movement of ideas, officers and the youth (Johnston, 2015; 2014). In July, Blackmore, the secretary of the Boy Scouts Association at the Colonial Headquarters in Accra, wrote to the Provincial Scout Commissioner of the Northern Territories Protectorate about "Boy Scouts - Correspondence With England". The Commissioner of Overseas of the Boy Scouts Association had returned the letters that made the English have the wrong impression about how to support West Africans:

Much annoyance is being caused by boys writing letters to persons in England and the Colonies stating that they are Scouts and asking people to send them presents and photographs. In several cases the boys promise to send monkeys, 
parrots, beads, etc. if the people to whom they write will send them school books, bibles, and prayer books.

At times the letters are couched in language not easily understood by people who have not lived in West Africa and are easily misconstrued. The Commissioner for Overseas has just returned another batch to me from England.

To have creditable Boy Scouts in the Gold Coast Colony, Blackmore ordered that the scout commissioners educate the Boy Scouts to terminate writing letters or be dismissed (ADM 56/1/338; ADM 56/1/317).

That quarter, the 1st Tamale Troop had 32 schoolboys. Eight schoolboys in each of the four patrols hyena, cat, owl, and hawk were to meet for instructions in the afternoons at four o'clock to five o'clock on Tuesdays, Thursdays, and Saturdays (Cat had replaced dove patrol when the Boy Scouts could call out with the cry of cats than doves). The schoolboys met two days in a week, Tuesdays and Saturdays. Saturday was not a school day and the schoolboys had domestic work such as laundry ensuring that the troop had mail and food in the canteen. As the schoolboys could not meet on Saturdays, a small number of schoolboys passed the Saturday Boy Scouts Tests.

Assistant Scout Commissioner Yarney was the only instructor. He taught the schoolboys the Law, Signs, the Union Jack, the Salute, the Scout Staff and Knotting for the Tenderfoot Tests and 25 Boy Scouts wore the Tenderfoot badge. For the Second Class Tests, 26 Boy Scouts accomplished the Month's Service, 11 Signalling (Semaphore), four Savings bank, and nine the Compass. The Boy Scouts who looked "happy and healthy" learned about "Cleanliness and Trustiness and Scout's Honour". The scoutmaster requested that a medical officer test First Aid and students should proceed to the hospital "to watch treatment of fresh wounds". Yarney deemed:

An "IREDI" Stretcher is badly needed for Ambulance Drill, and it is presumed can be made locally. It is an excellent form of Stretcher, and can be made of Canvas with strap for the Shoulder, and another strap to keep it in shape when folded, space for a pillow being attached to it.

Four Scout Poles are slipped through the seams of the Canvas, two going the long way, and two going the short way.

Two old scouts wore the uniform of the Boy Scouts but did not have shoulder knots and sought the 1st Tamale Troop strive to have a Rover Patrol.

Yarney wrote to the deputy camp chief that since scoutmaster Mahama was transferred from the Tamale Government School to Gambaga, Williams, the new teacher who passed the Second Class Test at the Accra Teacher Training Institution, should have a warrant as the scoutmaster of the Tamale Local Boy Scouts Association (ADM 56/1/317). The crowd exhibited "intense jubilation" when Williams, the master of the middle class, taught the Wolf Cubs the Great Howl and the Promise and planned their first examinations. The commissioner had not organized the Tenderfoot Tests. The patrol leaders taught the new schoolboys for the Tenderfoot Tests and the older schoolboys met Assistant Scout Commissioner Yarney for instruction and tests for the Second Class badge.

The tests for the Second Class badge were a Month's Service, First Aid, Cooking, Scout Pace, Firelighting, Signalling (Semaphore), Tracking or Kim's Game, Compass, Swimming and Savings bank. Major Wallace was at the Boy Scouts meetings on Wednesday(s) and at the First Aid examination on the first Friday of August. He invited Gardiner, the Provincial Inspector of Schools, to visit the 1st Tamale Troop and examine the Boy Scouts in First Aid. Assistant Scout Commissioner Yarney was gratified that Major Wallace was at the First Aid examination and 10 schoolboys made the grade. The 1st Tamale Troop imported First Aid requirements in 
a haversack from England and a second locally made Iredi Stretcher toward drills with the ambulance. The scout commissioner gave 13 shillings to buy the Iredi stretcher made from materials in the vicinity.

In the quarter ending September, the schoolboys requested Mondays, Wednesdays, and Fridays from 4:00 to 5:00 pm as the meeting days for instruction. In July, approximately 10 schoolboys, "the smart sort", graduated from the Tamale Government School and were admitted at the junior trade school at Yendi, where Captain Hendrie was the scout commissioner and Ward the literary instructor. Four schoolboys left Tamale Government School. The 1st Tamale Troop could accept 14 Wolf Cubs who had become full-grown Cub Scouts, for rudimentary instruction in the Boy Scouts. The 14 fresh schoolboys were allocated: three to hyena patrol, five to cat patrol, three to owl patrol, and three to hawk patrol to make the 1st Tamale Troop have 32 schoolboys, eight schoolboys in each of the patrols. The new schoolboys met Yarney instructing and testing Scout Pace, Firelighting, and Cooking with an objective that the Boy Scouts would become 2nd Class Scouts by September.

The graduates from the Cub Scouts learned Scout Pacing, Firelighting, and Cooking with the Boy Scouts but were not allowed to make the grade and had to first pass the Tenderfoot Tests. Tamale did not have road signs such as public places and miles to borders. For the Scout Pace, the Boy Scouts walked and ran 20 paces a mile from the residence of the mailman to the pillar on the border on the Gambaga road. Six schoolboys passed Firelighting. When the wet wood could not light, the Firelighting test was performed again. Patrol Leader Francis Kweku had the most hygienic and unsurpassed meal in Cooking. Boy Scout Williams was second. The assistant scout commissioner Yarney, scoutmasters Harruna and Williams, Essilfie a staff and an "uninvited guest" ate and were gratified with the schoolboys' proficiency in boiling rice and yams, and frying yams, eggs and pancakes.

Signalling and Kim's Game were analytical. Approximately one half of the 1st Tamale Troop could voluntarily send and receive Semaphore signals obligatory for the First Class badges. The speed to pass the Signalling examination was 20 letters a minute. On 19th September, all the patrol leaders, two seconds, and four Boy Scouts passed the Signalling examinations. Cat patrol leader Francis Kweku and Hawk patrol leader Mettle were the best at Signalling. The harsh weather did not allow Boy Scouts to walk in the open air for Tracking during scouting hours. The scout officers approved of Kim's Game about boys' memory of 16 of 24 things. The schoolboys who recalled the things were in high spirits but the dull minds did not like Kim's Game. The older schoolboys were perceptive than the younger schoolboys. Five schoolboys individually saved a shilling at the post office. Two of the five schoolboys increased their savings. The Boy Scouts had a lecture about frugality but various schoolboys squandered their coinage from sports prizes. The schoolboys who met the requirements of the compass tests knew the topic. The troop needed a prismatic compass for the Boy Scouts to apply their knowledge to the real word.

The Boy Scouts learned swimming at the end of the quarter. The games played were the Hare and the Hound, compass, relay races, chair games, cock fight, tossing for sides, Kim's Game, who's out and where's the whistle. The Deputy Camp Chief Major Walker-Leigh presented prizes, a spinning rope and a Gillwell knife for sense training and marksmanship competitions. Boy Scouts Owusu of Hawk and Abudulai Garaway of Owl won the prizes. The Boy Scouts had a service at which Yarney talked about the five wise and five foolish virgins. The Tamale Local Boy Scouts Association stripped arrogant Seidu Yakubu of his position as a patrol leader of Owl and suspended him for being disobedient. The chief scout Governor Guggisberg supported scouting in the Northern Territories when he gave the 1st Tamale Troop $£ 10$ from the Estimates for 1923-1924 
increasing the Tamale Boy Scouts Troop Fund to $£ 20$.

In October 1923, the 1st Tamale Boy Scout Troop had two instructors. Williams taught the junior class: Laws, Union Jack, and Knotting for the Tenderfoot Tests. Yarney taught the senior class who learned land rescue drill from the Life Savings book Major Wallace bought in England. The schoolboys swam in the dam. They did not have any Boy Scouts examinations; nonetheless, the hyena was the excellent patrol (ADM 56/1/317). Isaac Pappoe enrolled as a Rover Scout (ADM 56/1/338). In November, the ambulance haversack, knives, hatchets, and lifelines for First Aid arrived from England. Thirty schoolboys were in the troop. Eight of the schoolboys saved at the post office to concur with the scout Thrift Rule. Major Wallace made the troop have sports on the land flanked by the school and the court (ADM 56/1/317). Seidu Yakubu, who behaved badly and in the September quarter was stripped of his position as a patrol leader of Owl, was after a month, given back his position. The chief scout Governor Guggisberg pledged to the patrol system (ADM 56/1/317; ADM 56/1/338).

Many schoolboys went to their villages in November since schools were on vacation and the Boy Scouts did not have literature and could not figure out Boy Scouts tasks. During school vacation, the Local Boy Scouts Association stopped scouting and the scout commissioner went on leave (ADM 56/1/338).

\section{Conclusion}

During the 1920s, the scout officers and schoolboys at the Tamale Local Boy Scouts Association and the 1st Tamale Troop learned scouting, paid for scout uniforms, and performed at events officers organized. In December 1924, the government officers who were scout officers such as Major Wallace, Major Moreton, and Captain Sumner were at the Christmas races of the Southern Province and paid a subscription of one pound five shillings for the Southern Province Cup. In 1927, the Gold Coast Regiment and the Northern Territories Constabularies at the Constabulary Parade Grounds had combined sports such as tug-of-war that had eight European and African officers on two sides and catch weight that had one team from each government department. In June 1929, the race club committee thanked Fitt from the Gold Coast Regiment for working as the clerk of the race course $\left(\mathrm{ADM} 56 / 1 / 349^{8}\right)$. As the Europeans were on committees for races and paid subscriptions for races, they paid subscriptions to the Tamale Local Boy Scouts Association. The Africans who were government officers, teachers, parents, and guardians paid for the Boy Scout uniforms and gave offertory at church. The Boy Scouts wore the uniform to perform at the events of Boy Scout troops, church, and government officers. The Boy Scouts were in the principal veterinary officer's plan for the event at the construction of the Yamalaga bank and road from Salaga to Tamale. The event had scenes of magajia, women and persons from the Northern Territories Constabulary at the performance of womanhood in West Africa, tent pegging, a parade that roped in machine guns, guard mounting, a mounted drill and a foot drill. The scenes of Tamale were women at a banana well, weaving, tennis, a polo competition between the Northern Territories Constabulary and Europeans and mounted chiefs. The Boy Scouts would parade if they had paraphernalia.

The Boy Scouts needed paraphernalia to perform at Empire Day Celebrations in the Northern Territories and events in the metropole. In 1923, the 1st Tamale Boy Scout Troop curtsied the 1st Wa Troop celebrating their first Empire Day and the chief scout for Wales the Prince of Wales had a rally of Boy Scouts. In 1924, Major Walker-Leigh responded to the secretary of the Supreme Council that it was not possible to pay for a

\footnotetext{
${ }^{8}$ Public Records and Archives Administration Department, Accra, ADM 56/1/349 Tamale Races 18/7/23-26/3/31.
} 
Boy Scout or a team to the Imperial Boy Scout Jamboree at Wembley in England. The Great Stadium's arena was a football field. The Imperial Boy Scout Jamboree was a pageant that had an objective to educate Boy Scouts about the values and illustrative history that fitted England and the colonies in the British Empire and the British Empire Exhibition of 1924 (ADM 56/1/338; Johnston, 2015). As on school expeditions, the Boy Scouts would exhibit handicrafts, health, and service, and compare how the youth could fashion charitable activities and benevolence in the British Commonwealth (ADM 56/1/338). The 1st Tamale Troop could not have an international travel to the Imperial Boy Scout Jamboree and were at the Empire Day Celebrations in the Southern Province of the Northern Territories Protectorate (ADM 56/1/317). Scout Master Harruna requested from Osman, the secretary of the Boy Scouts Local Association, bugles for 10 Boy Scouts. Four Boy Scouts training as buglers were pulled towards the Empire Day Celebrations (ADM 56/1/338), as to football, camping and the solidarity of schoolboys in the Boy Scouts Association (Pryke, 1998).

\section{References}

Block, N., \& Proctor, T. (2009). Scouting frontiers youth and the scout movement's first century. Cambridge: Cambridge Scholars Publishing.

Johnston, S. (2014). "Only send boys of the good type": Child migration and the Boy Scouts Association, 1921-1959. The Journal of the History of Childhood and Youth, 7(3), 377-397.

Johnston, S. (2015). Courting public favour: The Boy Scouts Association and the accident of internationalism, 1907-29. Historical Research, 88(241), 508-529.

MacGaffey, W. (2006). A history of Tamale, 1907-1957 and beyond. Transactions of the Historical Society of Ghana, New Series, $10,109-124$

MacGaffey, W. (2009). The blacksmiths of Tamale: The dynamics of space and time in a Ghanaian industry. Journal of the International African Institute, 79(2), 169-185.

Pryke, S. (1998). The popularity of nationalism in the early British Boy Scouts Movement. Social History, 23(3), $309-324$. 